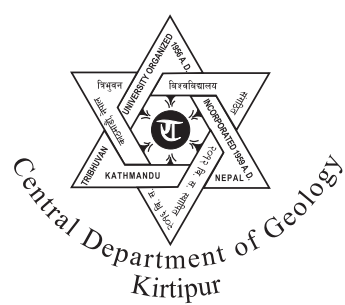

\title{
Petrogenesis of the augen gneisses from Mahesh Khola section, Central Nepal
}

\author{
Kamal Raj Regmi \\ Central Department of Geology, Tribhuvan University, Kirtipur, Kathmandu, Nepal
}

\begin{abstract}
In Mahesh Khola section, Central Nepal the augen gneisses are exposed within the rocks of the Kulikhani Formation of the Bhimphedi Group, Kathmandu Complex. Major and trace element were analysed in this study. The gneisses show peraluminous Stype nature with high mol. A/CNK ratios. Mantle normalised trace element patterns have similar character with the Early Paleozoic S-type granite of the Lachlan Fold Belt of Australia and the Paleozoic granites of the Tso-Morari Crystalline Complex, Lakadh, India. Hence most probably the protoliths of these gneisses are the porphyritic S-type granite that intruded in the rocks of the Bhimphedi Group during Caledonian Orogeny. However the granite is sheared, deformed and metamorphosed.
\end{abstract}

\section{INTRODUCTION}

The problem of origin and age of the augen genisses that occur in the Lesser Himalaya, Nepal is the most debated topic in petrogenesis (Pechêr and Le Fort 1977; Arita 1983; Kano 1984, 2004). However, there is no controversy about the composition of these gneisses. Many detail studies have been made by several authers regarding geochemistry and geochronology of the granites of the Kathmandu Crystalline Nappe (Le Fort et al. 1981, 1983; Sharma 1982; Scharer and Allegre 1983; Sharma 1992; Le Fort and Rai 1999), but such studies of augen gneisses of the Mahesh Khola section (also known as the Sheopuri Injection Gneisses), are limited (Johnson et al. 2001). U-Pb zircon chronology of these augen gneisses revealed an age of $471 \pm 12 \mathrm{Ma}$ (Johnson et al. 2001). This paper deals with the major and trace element geochemistry of the selected samples of the augen gneisses from the Mahesh Khola section to find their petrogenesis.

Corresponding author:

E-mail address: kamalregminp@yahoo.com
The study area is located in Central Nepal Higher Himalaya (Fig. 1). The mapping from the confluence of the Mahesh Khola and the Trisuli River towards upstream was carried out (Fig. 2) and selective sampling was made.

\section{GEOLOGICAL SETTING}

The geology of the Central Nepal has been well defined by Arita et al. (1973), Stocklin (1980), Rai et al. (1998), Rai (2001), Johnson et al. (2001), Gehrels et al. (2003) and others. According to Arita et al. (1973) the augen gneisses exposed along the Mahesh Khola section belong to the Sheopuri Injection Gneiss Zone (SIGZ) that is bounded by the TrishuliLikhu Fault in the north and the Kalpu-Dhanr Fault in the south. They described the SIGZ as a tectonic zone extending nearly east-west along the northern margin of the Kathmandu Valley from the Trisuli River to the Sunkoshi Tectonic Zone in the east. The SIGZ is terminated by the Thaple Fault in the west. The rock succession in the study area belongs to the Bhimphedi Group (Precambrian rocks) of the Kathmandu Complex, and the augen gneisses were 


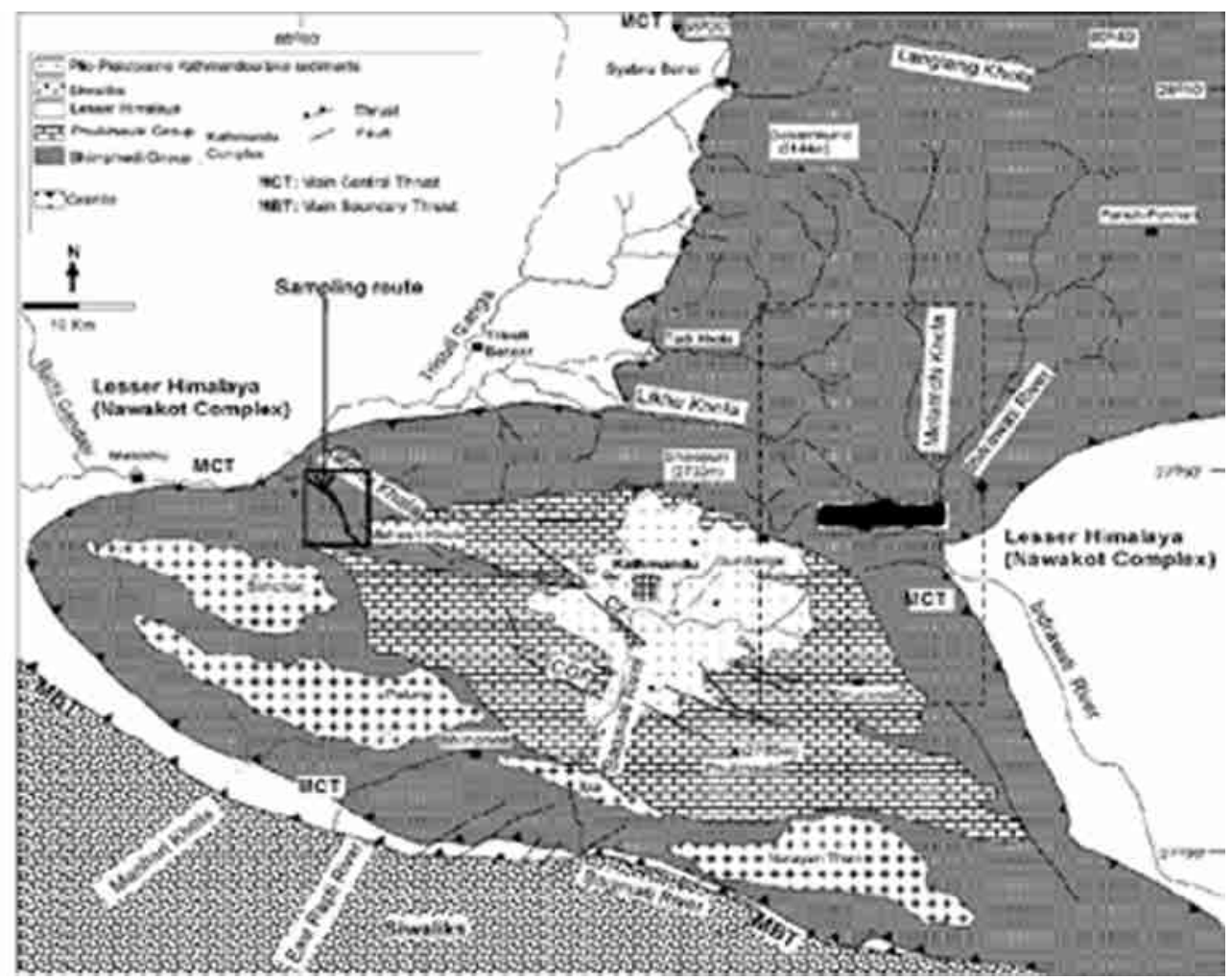

Fig. 1 Geological map of Central Nepal modified after Stocklin (1980) and location of the study route

injected in the rocks of the Kulekhani Formation. Upreti and Le Fort (1999) consider these augen gneisses as the Gosainkund Crystalline Nappe that are equivalent to the Higher Himalayan Crystallines in the north. According to Gehrels et al. (2003), the Lesser Himalayan rocks of the Central Nepal are overlain by the Higher Himalayan rocks (Formation I, II and III), the boundary being the Main Central Thrust (MCT). The Formation III consists basically of Cambro-Ordovician augen gneisses and is analogous with the Palung and related granites in the Kathmandu Nappe. They have interpreted the silllike augen gneisses of the Formation III to be emplaced along with the Early Paleozoic Thrust. Considering the interpretation of Gehrels et al. (2003), the augen gneisses of the Mahesh Khola section are related with the Formation III gneisses (Upreti and Le Fort 1999). Similarly, according to Rai et al. (1998), the augen gneisses of the studied section belong to the SIGZ of the Kathmandu, i.e., to the MCT sheet, and are bounded to both north and south by the MCT. The location of the MCT in the vicinity of the study area is also a matter of discussion. Upreti and Le Fort (1999) consider the existence of a number of sub-MCT sheets, whereas Johnson et al. (2001) consider the basal thrust of the Kathmandu Nappe locally known as the MT ast the southern continuation of the MCT of the Higher Himalaya.

Along the Mahesh Khola route, rock successions of the Kalitar Formation, Chisapani Quartzite, Kulikhani Formation and the Markhu Formation are exposed from the NW to the SE (Fig. 2). The Kalitar Formation comprises two mica schist (sometimes with sillimanite) and micaceous quartzite with bands of amphibolite. The Chisapani Quartzite comprises thin to thick bedded white quartzites. The Kulikhani Formation consists of garnetiferous schist and greengrey to light green micaceous quartzite. The Markhu Formation is characterised by dark grey biotite schist and quartzites with bands of marble and actinolite schists. In this formation a kyanite-bearing pegmatite 


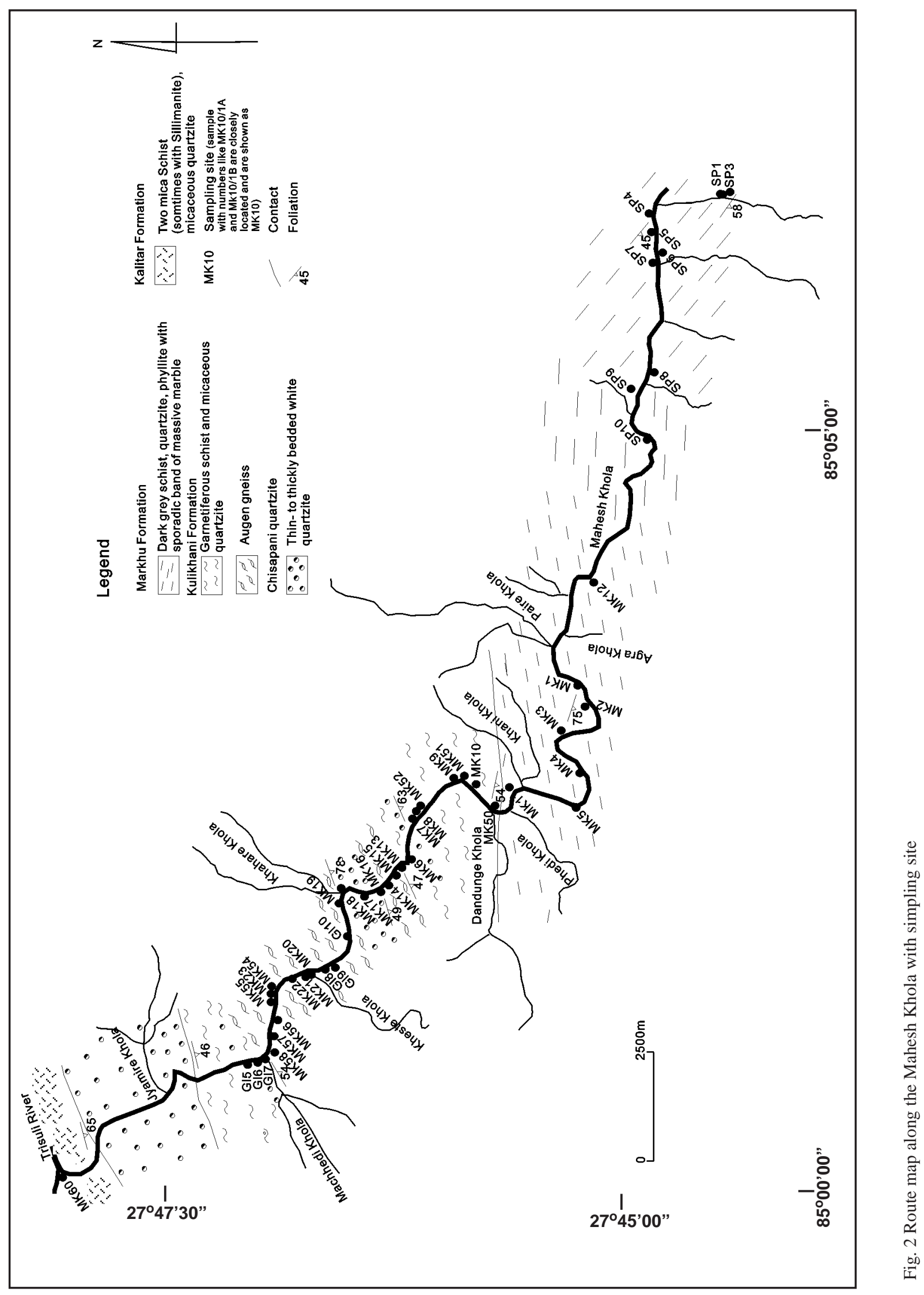


having discordant relationship with the schistocity was observed in location Sp7. The augen gneisses were intruded in the rocks of the Kulikhani Formation. The augen gneisses had concordant relationship with country rocks and were seen like sills.

\section{PETROGRAPHY OF AUGEN GNEISSES}

The augen gneisses in the study route are light grey. Many tourmaline bearing pegmatites and quartz veins, both concordant and discordant with folication of the gneisses are present. Plagioclase, K-feldspar, quartz, muscovite and biotite were the major constituents of these gneisses, whereas sphene, tourmaline, apatite, zircon, monazite, opaque mineral, and garnet were the accessory minerals. Staurolite with penetrating twinning was observed in MK 23. K-feldspar was mainly orthoclase with minor perthitic and myrmekitic intergrowths that were spradically sericitized, and frequently includes muscovite, biotite and quartz. Augens upto $40 \mathrm{~mm}$ in diameter were represented by K-feldspars.

\section{GEOCHEMISTY OF AUGEN GNEISSES}

Major and trace elements from the 17 selected rock samples (Table 1) were analysed using Philips PW1404 X-ray fluorescence spectrometer with Rh side-window tube at the geochemical laboratory of Hokkaido University, Japan in 1999. The details of analytical method, accuracy and precision of analysis are given in Tanaka and Orihashi (1995). Analytical error of the instrument is $\pm 0.2 \%$ for the major elements and $\pm 5 \%$ for trace elements. Two or more chips of rock samples, cut normal to foliation were powdered and used for analysis. Powder of the rock samples was heated upto $1000^{\circ} \mathrm{C}$ for 3 hours to determine the ignition loss, which was found to be less than $1 \mathrm{wt} \%$, and was discarded from further consideration.

The variation in $\mathrm{SiO}_{2}$ content was from 65.13 to $73.7 \mathrm{wt} \%$, whereas the total alkali content ranged from 6.14 to $8.04 \mathrm{wt} \%$. The gneisses had high $\mathrm{K}_{2} \mathrm{O}$ content with $\mathrm{K}_{2} \mathrm{O} / \mathrm{Na}_{2} \mathrm{O}$ ratios exceeding 1 except for the samples MK23/1A, MK23/1B and MK18/1A. These samples had higher molar $\mathrm{A} / \mathrm{CNK}$ ratio (where, $\mathrm{A}=\mathrm{Al}_{2} \mathrm{O}_{3}, \mathrm{C}=\mathrm{CaO}, \mathrm{N}=\mathrm{Na}_{2} \mathrm{O}, \mathrm{K}=\mathrm{K}_{2} \mathrm{O}$ ) indicating their peraluminous nature (Fig. 3).

Most of the major elements such as $\mathrm{Al}_{2} \mathrm{O}_{3}, \mathrm{TiO}_{2}$, $\mathrm{Fe}_{2} \mathrm{O}_{3}, \mathrm{MnO}$ and $\mathrm{MgO}$ had negative correlation with
$\mathrm{SiO}_{2}$ (Fig. 4). Very poor correlation existed between $\mathrm{SiO}_{2}$ and $\mathrm{K}_{2} \mathrm{O}, \mathrm{Na}_{2} \mathrm{O}, \mathrm{CaO}$ or $\mathrm{P}_{2} \mathrm{O}_{5}$. These trends are controlled by crystallisation of the major rock forming minerals, particularly $\mathrm{Kf}+\mathrm{Pl}+\mathrm{Bt} \pm \mathrm{Ms}$ assemblage.

The gneisses had high $\mathrm{Rb}$ and low $\mathrm{Sr}$ contents (Table 1). Correlation patterns of selected trace elements with $\mathrm{Zr}$ are shown in Fig. 5 to check fractionation of $\mathrm{Kf}+\mathrm{Pl}+\mathrm{Bt} \pm \mathrm{Ms}$ assemblage. $\mathrm{Rb}$ content decreases with increasing $\mathrm{Zr}$. Positive correlations are shown by $\mathrm{Nb}, \mathrm{Sr}, \mathrm{Ba}, \mathrm{La}$ and $\mathrm{Ni}$ with $\mathrm{Zr}$. Zr has poor correlation with $\mathrm{Y}, \mathrm{Th}, \mathrm{Ga}$ and $\mathrm{Zn}$.

\section{DISCUSSIONS}

The augen gneisses mostly plot in monzogranite field (Fig. 6), except one sample that plots in granodiorite field based on granitoid classification of Streckeisen (1976). These gneisses exhibit narrow range of $\mathrm{SiO}_{2} / \mathrm{Al}_{2} \mathrm{O}_{3}$ ratio which supports partial melting. There was no metasomatism and solid-state segregation which would have otherwise yield variable ratio. The role of partial melting is also supported by the presence of migmatites that are abundant in the study area.

$\mathrm{Zr}$ which is the most immobile element decreases with $\mathrm{SiO}_{2}$. Decrease of $\mathrm{Rb}$ and $\mathrm{Zr}$, and increase of $\mathrm{Nb}, \mathrm{Sr}, \mathrm{La}, \mathrm{Ni}$ and $\mathrm{Ba}$ with $\mathrm{SiO}_{2}$ content are controlled

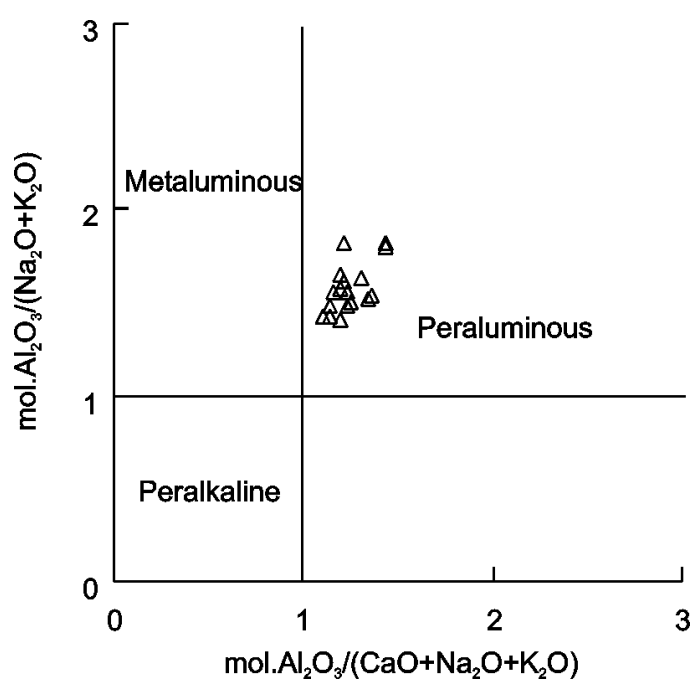

Fig. 3 Shand's (1946) Index of the augen gneisses from the Mahesh Khola section 


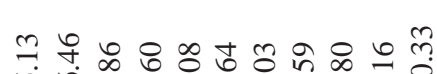

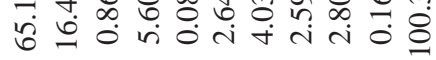
ले 등ำ त्र

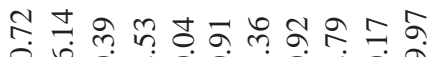

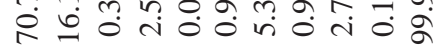
농

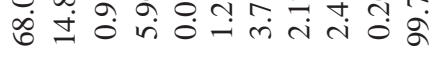

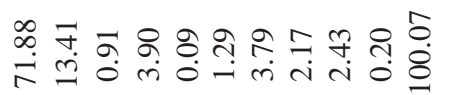

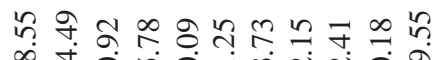

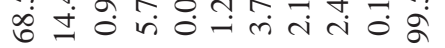

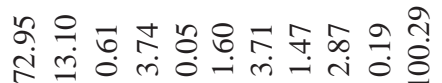
กำ रें

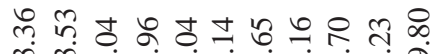
लू

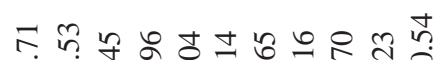

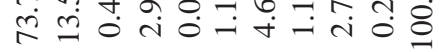

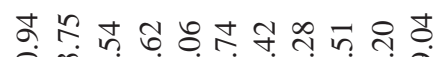

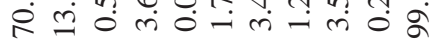

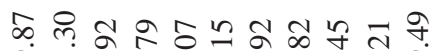

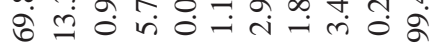
ㅊำ वें

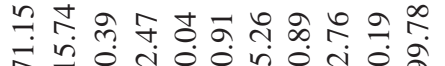

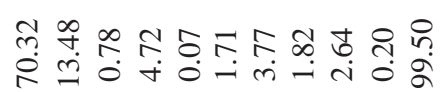

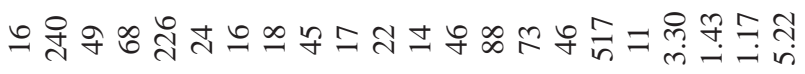

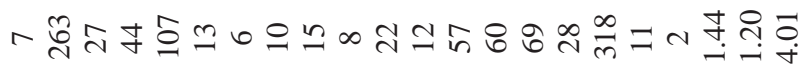

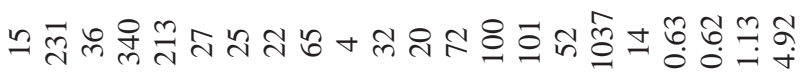
송

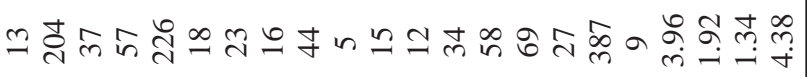

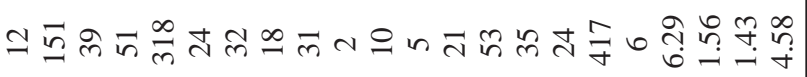

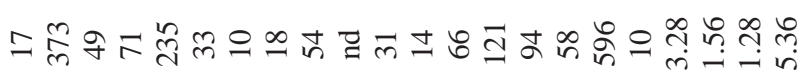

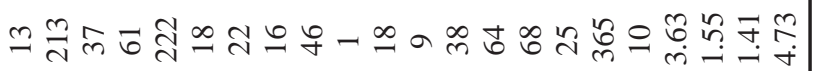

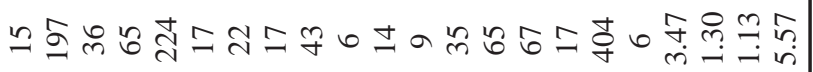

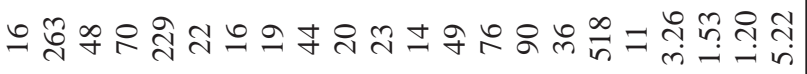

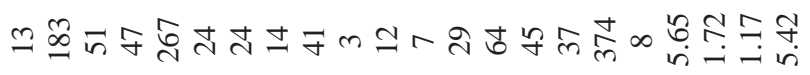

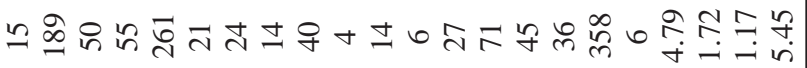

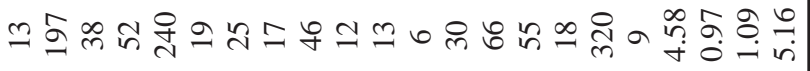

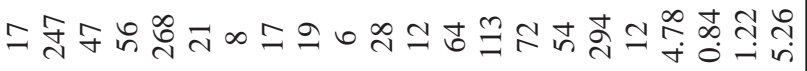

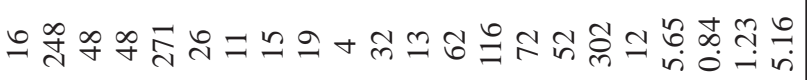

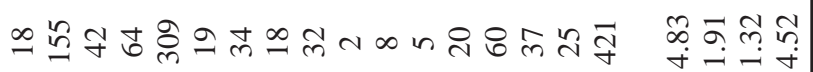

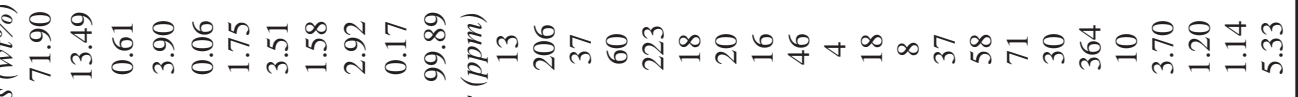


by crystallisation of $\mathrm{Kf}+\mathrm{Pl}+\mathrm{Bt} \pm \mathrm{Ms}$ assemblage.

In the alkali versus ferromagnesian and alumina versus ferromagnesian plots (Fig. 7), the gneisses showed very similar trends to that of peraluminous S-type granites after Patino Douce (1999). Primordial mantle normalised trace elements patters (normalizing values are after McDonough et al. 1992) show that the gneisses are depleted in $\mathrm{Ba}, \mathrm{Nb}, \mathrm{Sr}$ and $\mathrm{Ti}$ (Fig. 8a) which matches well with the Paleozoic S-type granites (Fig. 8b) of the Tso-Murari Complex, Ladakh, India (Islam et al. 2006), and the Lachlan Fold Belt of Australia (Wyborn et al. 1992). Besides, the U-Pb zircon chronology of the augen gneisses has magmatic age of nearly $470 \mathrm{Ma}$, and $\mathrm{U}-\mathrm{Pb}$ monazite chronology from pegmatites is $21.5 \pm 0.5 \mathrm{Ma}$ (Johnson et al. 2001). It is inferred that the magmatic age of nearly $470 \mathrm{Ma}$ was the time time of emplacement of the protolith of augen gneisses (porphyritic granite) and age of $\sim 21 \mathrm{Ma}$ of pegmatites is the time of deformation and metamorphism of the granites into the augen gneisses. The augen gneisses have concordant relationships with the country rocks and are also not much thick. Hence, the protolith of the augen gneisses were most probably injected into the rocks of the Kulikhani Formation as a sill. Considering their exposed position and relationship with associated
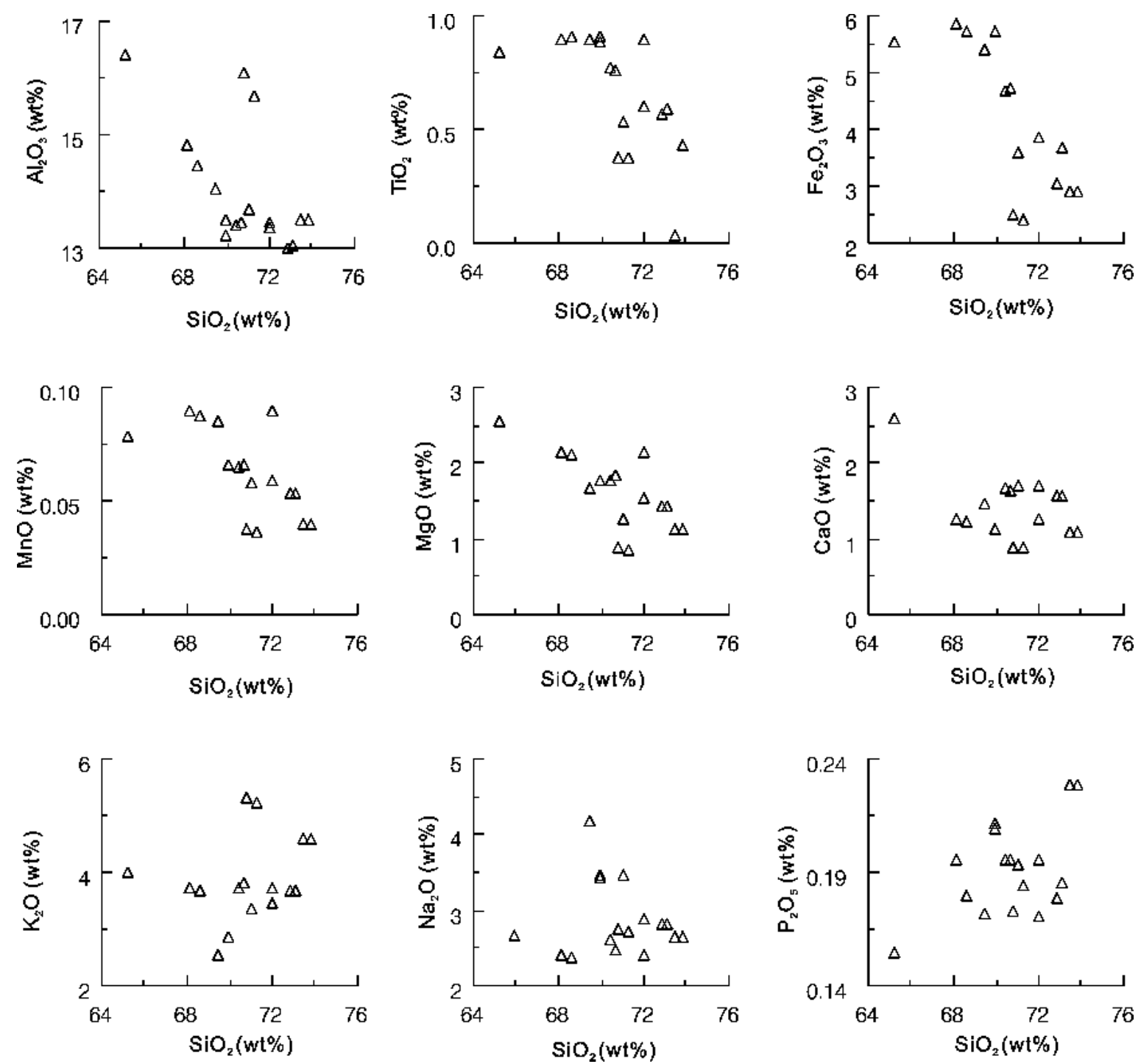

Fig. 4 Harker's variation diagram of the augen gneisses from the Mahesh Khola section 
Petrogenesis of the augen gneisses from Mahesh Khola section, Central Nepal
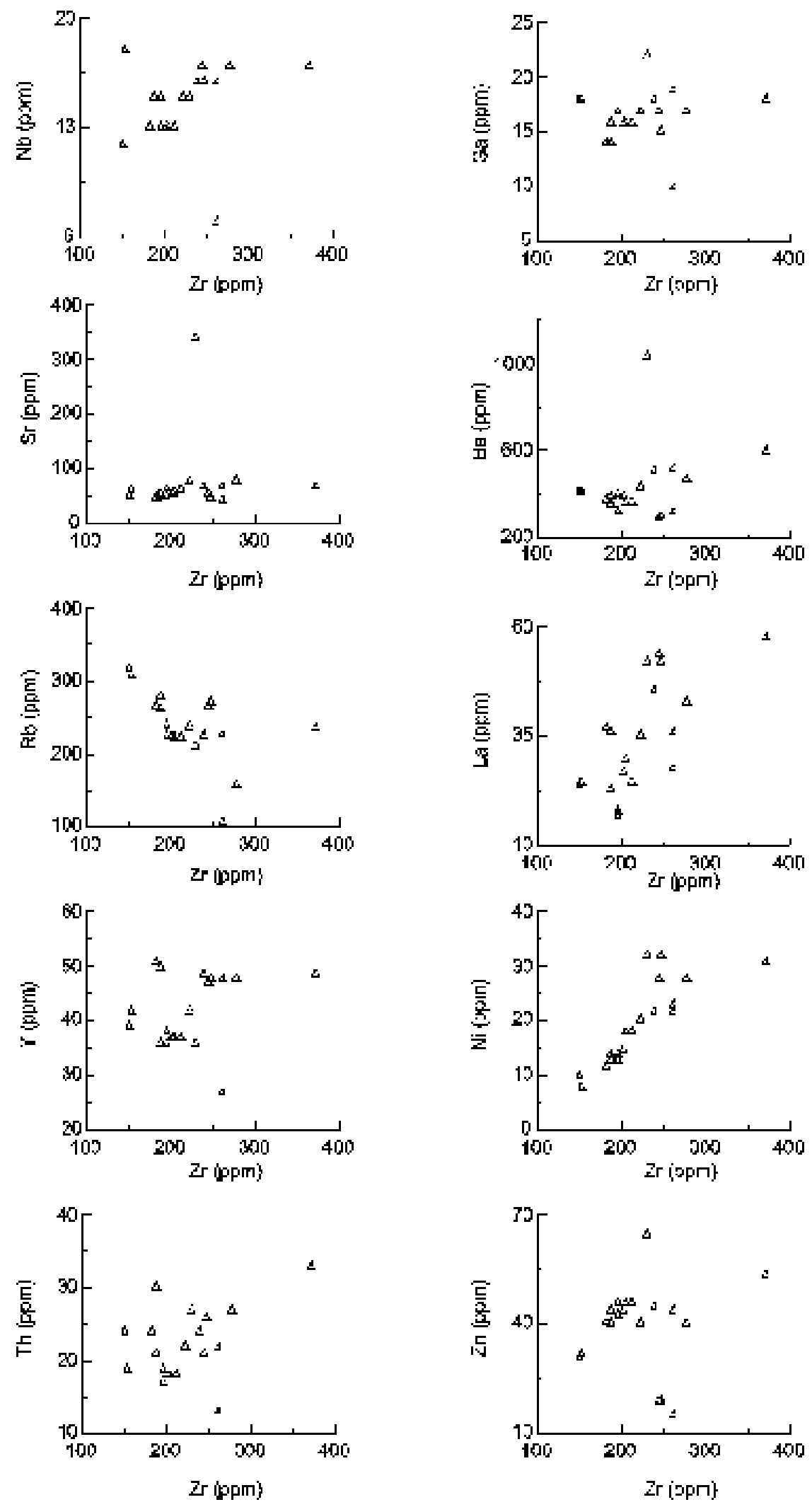

Fig. 5 Zircon versus selected trace elements of the augen gneisses from the Mahesh Khola section 


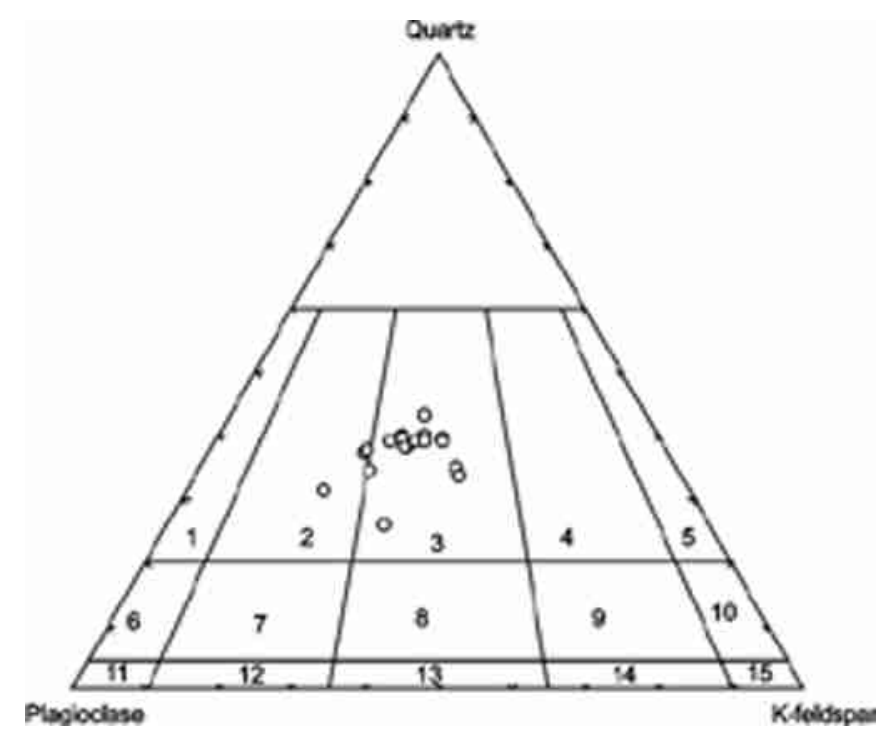

Fig. 6 The augen gneisses from the Mahesh Khola section plotted on the granitoid classification diagram of Streckeisen (1976). Th compositional fields are: 1-Tonalite, 2-Granodiorite, 3-Monzogranite, 4-Syenogranite, 5-Alkali Feldspar Granite, 6-Quartz Diorite, 7-Quartz Monzodiorite, 8-Quartz Monzonite, 9-Quartz Syenite, 10-Quartz Alkali Feldspar Granite, 11-Gabbro, Diorite and Anorthosite, 12-Monzodiorite, 13-Monzonite, 14-Syenite, and 15-Alkali Feldspar Syenite
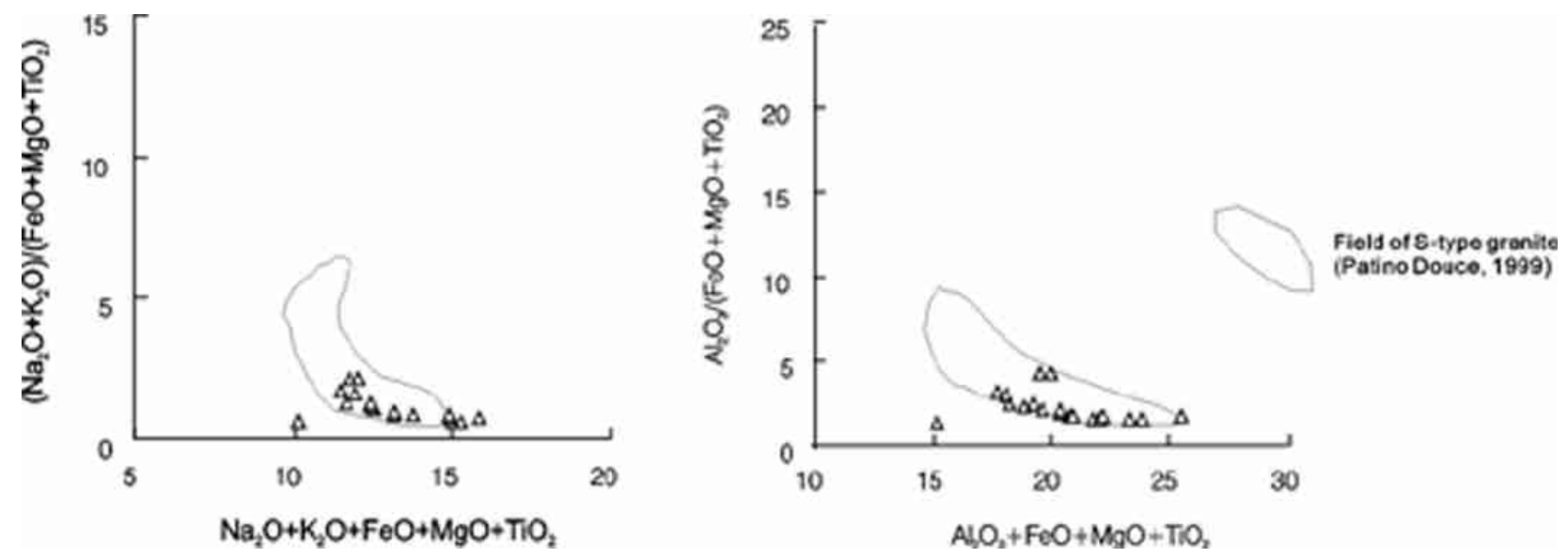

Fig. 7 Plots of alkalis versus ferromagnesian and alumina versus ferromagnesian compenents of the augen gneisses from the Mahesh Khola section

rocks, the protoliths of the augen gneisses are interpreted to be the Paleozoic porphyritic granites which were sheared and metamorphosed during Tertiary. As these rocks show peraluminous S-type nature, the protoliths must be the products of melting of crustal rocks. Quartzo-feldspathic material sturated with alumina can be potential source for the protoliths.

\section{CONCLUSIONS}

The protoliths of the augen gneisses must be originated from melting of crustal rocks, as the augen gneiss show peraluminous S-type nature. The primordial mantle normalised trace element pattern of studied augen gneisses is very similar with the 


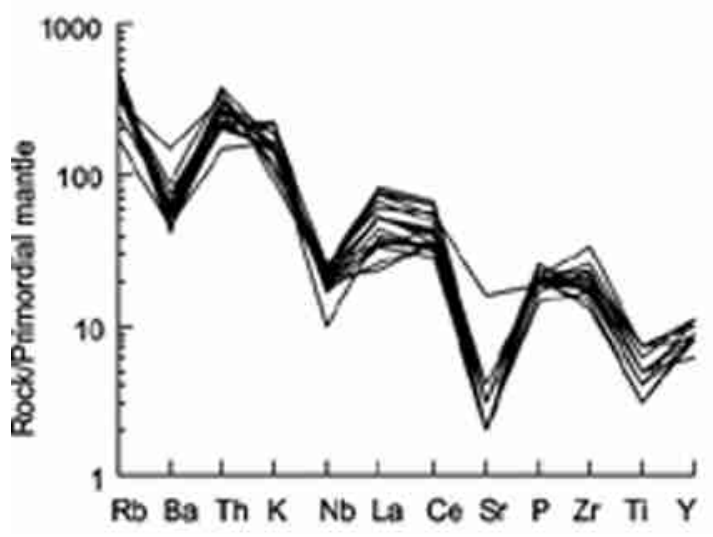

(a)

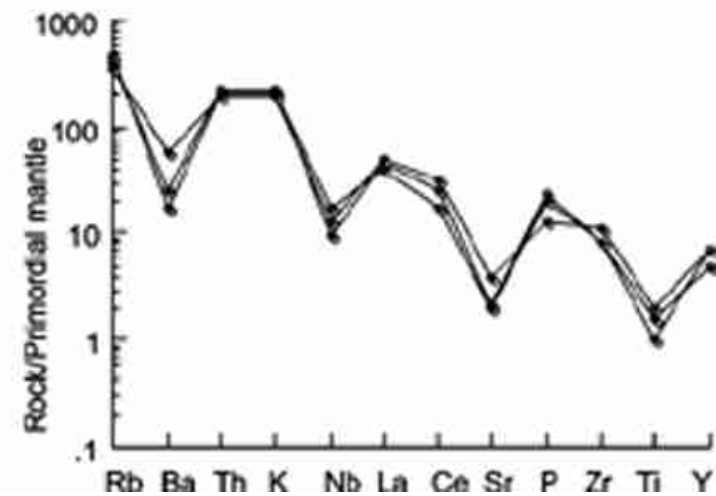

(b)

Fig. 8 Multi-element spider diagrams (a) Augen gneisses from the Mahesh Khola section (normalising values are after McDOnough et al. 1992) and (b) Paleozoic S-type granites from the Tso-Morari Crystalline Complex, Ladakh, India (data after Islam et al. 2006)

pattern of the Paleozoic granites from Tso-Morari Complex, Ladakh, India, and Lachlan Fold Belt of Australia. Hence the augen gneisses are interpreted to be deformed porphyritic granitic intrusive (sill) which intruded in the rocks of the Kathmandu Complex during Caledonian Orogeny.

\section{ACKNOWLEDGEMENTS}

Author is greatly thankful to Ministry of Education, Science, Sports and Culture, Japan for providing a research grant. Author is thankful to Prof. K Arita of Hokkaido University Museum, Sapporo, Japan for kindly hosting during chemical analysis of the rocks.

\section{REFERENCES}

Arita, K., Ohta, Y., Akiba, C. and Maruo, Y., 1973. Kathmandu Region. In Geology of the Nepal Himalayas (S. Hashimoto, Y. Ohta and C. Akiba eds.). Saikon Publishing Co. Ltd., Tokyo, pp. 99145.

Arita, K., 1983. Origin of the inverse metamorphism of the Lower Lesser Himalayas, Central Nepal. Tectonophysics, v. 95 , pp. 4360.

Gehrels, G.E., DeCelles, P.E., Martin, A., Ojha, T.P., Pinhassi,

G. and Upreti, B.N., 2003. Initiation of the Himalayan Orogen as an Early Paleozoic Thin-Skinned Thrust Belt. Geological Society of America Today, pp. 49. Islam, R., Rao, R., Gururanja, N.S., Rai, H. and Khanna,
P.P., 2006. Geochemical, geochronological and petrogenetic studies of the granitoids from the TsoMorari COmplex, Ladakh, Jammu and Kashmir. Journal of Geological Society of India, v. 68, pp. 7286.

Johnson, M.R.W., Oliver, G.J.H., Parrish, R.R. and Johnson, S.P., 2001. Synthrusting metamorphism, cooling and erosion of the Himalayan Kathmandu complex, Nepal. Tectonics, v. 20, pp. 394415.

Kano, T., 1984. Occurrence of augen gneisses in the Nepal Himalayas. Journal of Nepal Geological Society. Special Issue, v. 4, pp. 121139.

Le Fort, P., and Rai, S.M., 1999. Pre-Tertiary felsic magmatism of the Nepal Himalaya. Recycling of continental crust. Journal of Asian Earth Sciences, v. 17, pp. 607628.

Le Fort, p., Debon, F. and Sonet, J., 1981. Lower Paleozoic emplacement for granites and granitic gneisses of the Kathmandu Nappe. Central Terra Cog., Special Issue, v. 30, pp. 7284.

Le Fort, p., Debon, F. adn Sonet, J., 1983. The lower Paleozoic "Lesser Himalayan" granitic belt. Emphasis on the Simchar Pluton of central Nepal. In Granites of Himalaya, Karakorum and Hindu-Kush (F. A. Shams, ed.) Institute of Geology, Punjab University, Lahore (Pakistan), pp. 235255.

McDonough, W.F., SUn, S., Ringwood, A.E., Jagoutz, E. adn Hofmann, A.W., 1992. Potassium rubidium and cesium in the earth adn moon and the evolution of the earth's mantle. Geochimia Cosmochimia Acta, v. 56, pp. 10011002.

Patino Douce. A.E., 1999. What do experiments tell us 
about the relative contributions of crust and mantle to the origin of granitic magmas?. Geological Society of London, Special Publication, 168, pp. 5575. Pechêr, A. and Le Fort, P., 1977. Origin and significance of teh Lesser Himalayan augen gneisses. In Ecologie at geologie de l'Himalaya (C. Jest, ed.) C.N.R.S. Paris, Coll. Int., v. 268, Science de la Terre, Ed. Cent. National Reserch, Science, Paris, pp. 319329.

Rai, S.M., Le Fort, P. and Upreti, B.N., 1998. Pressuretemperature evolution in the Kathmandu and Gosainkund. Journal of Asian Earth Sciences, v. 16, pp. 283291.

Rai, S.M., 2001. Geology, geochemisty and radiochronology of the Kathmandu and Gosainkund Crystalline Nappes, central Nepal Himalaya. Journal of Nepal Geological Society, v. 25 (Special Issue), pp. 135155.

Sharma, M.P., 1982. moneralogy and geochemistry of Palung granite massif. Journal of Nepal Geological Society, v. 2, pp. 3038.

Scharer, U. and Allegre, C.J., 1983. The Palung granite (Himalaya); high resolution $\mathrm{U}-\mathrm{Pb}$ systematics in zircon and monazite: Earth and Planetary Science Letters, v.
63, pp. 423432.

Streckeisen, A.L., 1976. To each plutonic rock its proper name. Earth Science Reviews, v. 12, pp. 133.

Stöcklin, J., 1980. Geology of Nepal and its regional frame. Journal of Geological Society of London, v. 137, pp. 134.

Tanaka, R. and Orihashi, Y., 1995. XRF analysis of major and trace elements for silicate rocks using low dilution ratio fused glass bead. HUEPS Technical Report-2. Division of Earth and Planetary Sciences, Graduate School of Science, University, Sapporo, Japan, 35p.

Upreti, B.N. and Le Fort, P., 1999. Lesser Himalayan crystalline nappes of Nepal: Problems of their origin. In: Himalaya and Tibet: Mountain roots and Mountain tops (A. Macfarlane, R.B. Sorkhabi and J. Quade eds.), Geological Society of America, Special paper, v. 328, pp. 225238.

Wyborn, L.A.I., Wyborn, D., Warren, R.G. and Drummond, B.J., 1992. Proterozoic granite types in Australia: Implication for lower crust composition, structure and evolution. Transaction Royal Society of Edinburg. Earth Science, v. 83, pp. 201209. 